\title{
Protein Kinase $\mathrm{A}$ and $\mathrm{Ca}_{\mathrm{v}} \mathrm{1}$ (L-Type) Channels Are Common Targets to Facilitatory Adenosine $A_{2 A}$ and Muscarinic $M_{1}$ Receptors on Rat Motoneurons
}

\author{
Laura Oliveira Paulo Correia-de-Sá \\ Laboratório de Farmacologia, Unidade Multidisciplinar de Investigação Biomédica, Instituto de \\ Ciências Biomédicas de Abel Salazar, Universidade do Porto, Porto, Portugal
}

\author{
Key Words \\ Neuromuscular transmission - Adenosine $A_{2 A}$ \\ receptors $\cdot$ Muscarinic $M_{1}$ receptors - Protein kinase $A$. \\ Protein kinase $\mathrm{C} \cdot \mathrm{Ca}_{\mathrm{v}} 1$ (L-type) channels • \\ Acetylcholine release
}

\begin{abstract}
At the rat motor endplate, pre-synaptic facilitatory adenosine $A_{2 A}$ and muscarinic $M_{1}$ receptors are mutually exclusive. We investigated whether these receptors share a common intracellular signalling pathway. Suppression of $\mathrm{McN}-\mathrm{A}-343$-induced $\mathrm{M}_{1}$ facilitation of $\left[{ }^{3} \mathrm{H}\right] \mathrm{ACh}$ release was partially recovered when CGS21680C (an $A_{2 A}$ agonist) was combined with the cyclic AMP antagonist Rp-cAMPS. Forskolin, rolipram and 8-bromo-cyclic AMP mimicked CGS21680C blockade of $\mathrm{M}_{1}$ facilitation. Both Rp-cAMPs and nifedipine reduced augmentation of $\left[{ }^{3} \mathrm{H}\right] \mathrm{ACh}$ release by McN-A-343 and CGS21680C. Activation of $\mathrm{M}_{1}$ and $\mathrm{A}_{2 \mathrm{~A}}$ receptors enhanced $\mathrm{Ca}^{2+}$ recruitment through nifedipine-sensitive channels. Nifedipine inhibition revealed by McN-A-343 was prevented by chelerythrine (a PKC inhibitor) and Rp-cAMPS, suggesting that $\mathrm{Ca}_{\mathrm{v}} 1$ (L-type) channels phosphorylation by PKA and PKC is required. Rp-cAMPS inhibited $\left[{ }^{3} \mathrm{H}\right] \mathrm{ACh}$ release in the presence of phorbol 12-myristate 13-acetate, but PKC inhibition by chelerythrine had no effect on release in the presence of 8-bromo-cyclic AMP. This suggests that the
\end{abstract}

involvement of PKA may be secondary to $M_{1}$-induced $P K C$ activation. In conclusion, competition of $M_{1}$ and $A_{2 A}$ receptors to facilitate $A C h$ release from motoneurons may occur by signal convergence to a common pathway involving PKA activation and $\mathrm{Ca}^{2+}$ influx through $\mathrm{Ca}_{\mathrm{v}} 1$ (L-type) channels.

Copyright (C) 2005 S. Karger AG, Basel

\section{Introduction}

Functional evidence that adenosine controls synaptic transmission through a sophisticated interplay between its own receptors (namely adenosine inhibitory $\mathrm{A}_{1}$ and facilitatory $\mathrm{A}_{2 \mathrm{~A}}$ receptors) and receptors for other neurotransmitters/neuromodulators (e.g. acetylcholine (ACh), glutamate, $\gamma$-aminobutyric acid, neuropeptides) has been provided [for review, see 1]. At the rat neuromuscular junction, facilitation of ACh release may be balanced through tonic activation of pre-synaptic muscarinic $\mathrm{M}_{1}$ and adenosine $\mathrm{A}_{2 \mathrm{~A}}$ receptors [2]. While the muscarinic $\mathrm{M}_{1}$-positive feedback mechanism is operative, the adenosine $\mathrm{A}_{2 \mathrm{~A}}$-receptor-mediated facilitation is suppressed. In contrast, the increasing tonic activation of $A_{2 A}$ receptors by adenosine generated during neuronal firing from the catabolism of released adenine nucleotides counteracts $\mathrm{M}_{1}$ facilitation of $\mathrm{ACh}$ release and may be responsible by changes in the efficacy profile of musca-

\section{KARGER}

Fax +4161306 1234 E-Mail karger@karger.ch www.karger.com
(C) $2005 \mathrm{~S}$. Karger AG, Basel

$1424-862 X / 05 / 0145-0262 \$ 22.00 / 0$

Accessible online at:

www.karger.com/nsg
Paulo Correia-de-Sá, MD, PhD

Laboratório de Farmacologia, Unidade Multidisciplinar de Investigação Biomédica

Instituto de Ciências Biomédicas de Abel Salazar, Universidade do Porto

L. Prof. Abel Salazar, 2, PT-4099-003 Porto (Portugal)

Tel. +35122 2062243, Fax +35122 2062252, E-Mail farmacol@icbas.up.pt 
rinic agonists. These findings may explain some controversies found in literature about the muscarinic regulation of ACh release from stimulated motor nerve terminals [3], although it remains to be elucidated the signalling mechanism involved in the cross-talk between facilitatory $\mathrm{M}_{1}$ and $\mathrm{A}_{2 \mathrm{~A}}$ receptors at the rat motor endplate.

Muscarinic $\mathrm{M}_{1}$ receptors typically couple via subunits of $\mathrm{G}_{\mathrm{q} / 11}$ protein family to phospholipase $\mathrm{C}$ leading to inositol 1,4,5-trisphosphate ( $\mathrm{IP}_{3}$ )-sensitive intracellular $\mathrm{Ca}^{2+}$ mobilization and to protein kinase $\mathrm{C}$ (PKC) activation [4]. At the rat motor nerve terminals, facilitatory adenosine $\mathrm{A}_{2 \mathrm{~A}}$ receptors are positively coupled to the adenylate cyclase/cyclic AMP transducing system [5]. It has also been shown that blockade of $\mathrm{Ca}_{\mathrm{v}} 1$ (L-type) channels, which do not ordinarily participate in the release process [6-8], may attenuate facilitation of ACh release induced by neuronal $\mathrm{M}_{1}$ and $\mathrm{A}_{2 \mathrm{~A}}$ receptors $[9,10]$. The activity of pre-synaptic $\mathrm{Ca}_{\mathrm{v}} 1$ (L-type) channels may be modulated by a membrane-delimiting pathway involving G-proteins, as well as by phosphorylation caused by cytoplasmic messengers. High intracellular cyclic AMP levels enhance the open probability, reduce the rundown, and recruit newly functioning $\mathrm{Ca}_{\mathrm{v}} 1$ (L-type) channels [11]. Likewise, PKC-induced phosphorylation may increase quantal $\mathrm{ACh}$ release by opening quiescent $\mathrm{Ca}_{\mathrm{v}} 1$ (L-type) channels in frog motor nerves at resting potential [12] and in neurons projecting to the rat urinary bladder [13].

These findings prompted us to study whether the negative interplay between $M_{1}$ and $A_{2 A}$ receptors could result from competition for activation of common signalling molecules, in particular protein kinase $\mathrm{A}$ (PKA) and $\mathrm{PKC}$ which might trigger $\mathrm{Ca}^{2+}$ influx through quiescent $\mathrm{Ca}_{\mathrm{v}} 1$ (L-type) channels, in order to break neurotransmitter overflow during synchronous activation of pre-synaptic facilitatory receptors. Due to the anatomical complexity of the mammalian neuromuscular junction, it is hard to perform biochemical studies without a significant contamination of skeletal muscle metabolism. Therefore, the results presented here reflect the actions of pharmacological tools capable of interfering with a given intracellular signalling pathway.

\section{Materials and Methods}

\section{Preparation and Experimental Conditions}

Rats (Wistar, 150-200 g) of either sex (Charles River, Barcelona, Spain) were kept at a constant temperature $\left(21^{\circ} \mathrm{C}\right)$ and a regular light (06:30-19:30 h)/dark (19:30-06:30 h) cycle, with food and water ad libitum. The animals were killed after stunning followed by exsanguinations. Animal handling and experiments fol- lowed the guidelines of the International Council for Laboratory Animal Science. The experiments were performed on left phrenic nerve-hemidiaphragm preparations (4-6 mm width). Each muscle was superfused with gassed $\left(95 \% \mathrm{O}_{2}\right.$ and $\left.5 \% \mathrm{CO}_{2}\right)$ Tyrode's solution $(\mathrm{pH} 7.4)$ containing $(\mathrm{m} M): \mathrm{NaCl} 137, \mathrm{KCl} 2.7, \mathrm{CaCl}_{2}$ 1.8, $\mathrm{MgCl}_{2} 1, \mathrm{NaH}_{2} \mathrm{PO}_{4} 0.4, \mathrm{NaHCO}_{3} 11.9$, glucose 11.2 and choline 0.001 , at $37^{\circ} \mathrm{C}$.

The procedures used for labeling the preparations and measuring evoked $\left[{ }^{3} \mathrm{H}\right] \mathrm{ACh}$ release were as previously described [15], with minor modifications. Phrenic nerve-hemidiaphragm preparations were mounted in 3-ml capacity Perspex chambers heated to $37^{\circ} \mathrm{C}$. Nerve terminals were labeled for 40 min with $1 \mu M\left[{ }^{3} \mathrm{H}\right]$ choline (specific activity $2.5 \mu \mathrm{Ci} \mathrm{nmol}^{-1}$ ) under electrical stimulation at a frequency of $1 \mathrm{~Hz}(0.04 \mathrm{~ms}$ duration, $8 \mathrm{~mA})$. The phrenic nerve was stimulated with a glass-platinum suction electrode placed near the first division branch of the nerve trunk to avoid direct contact with muscle fibers. Washout of the preparations was performed for $60 \mathrm{~min}$, by superfusion $\left(15 \mathrm{ml} \mathrm{min}^{-1}\right)$ with Tyrode solution supplemented with the choline uptake inhibitor, hemicholinium-3 $(10 \mu M)$. Tritium outflow was evaluated by liquid scintillation spectrometry ( $\%$ counting efficiency: $40 \pm 2 \%$ ) after appropriate background subtraction using 2-ml bath samples collected automatically every $3 \mathrm{~min}$. After the loading and washout periods, the preparation contained $(5,542 \pm 248) \times 10^{3} \mathrm{dpm} \mathrm{g}^{-1}$ wet weight of tissue and the resting release was $(132 \pm 12) \times 10^{3} \mathrm{dpm} \mathrm{g}^{-1}(\mathrm{n}=$ 8 ). The fractional release was calculated to be $2.38 \pm 0.14 \%$ of the radioactivity present in the tissue at the first collected sample.

$\left[{ }^{3} \mathrm{H}\right] \mathrm{ACh}$ release was evoked by electrical stimulation of the phrenic nerve with trains of 750 supramaximal intensity pulses of $40 \mu$ s duration delivered at a frequency of $5 \mathrm{~Hz}$. Two stimulation periods were used, starting respectively at 12 th $\left(S_{1}\right)$ and 39 th $\left(S_{2}\right)$ minutes after the end of washout (zero time) (see e.g. fig. 1). Electrical stimulation increased only the release of $\left[{ }^{3} \mathrm{H}\right] \mathrm{ACh}$ in a Ca ${ }^{2+}$ - and tetrodotoxin-sensitive manner [10], while the output of $\left[{ }^{3} \mathrm{H}\right]$ choline remained unchanged [16]. Therefore, evoked $\left[{ }^{3} \mathrm{H}\right] \mathrm{ACh}$ release was calculated by subtracting the basal tritium outflow from the total tritium outflow during the stimulation period [cf. 15].

\section{Drug Effects and Pharmacological Interactions}

Test drugs were added $15 \mathrm{~min}$ before $\mathrm{S}_{2}$ and were present up to the end of the experiments. The percentage change in the ratio between the evoked $\left[{ }^{3} \mathrm{H}\right] \mathrm{ACh}$ release during the two stimulation periods $\left(\mathrm{S}_{2} / \mathrm{S}_{1}\right)$ relative to that observed in control situations (in the absence of test drugs) was taken as a measure of the effect of the tested drugs. When we evaluated changes in the effect of drugs induced by a modifier, the modifier was applied 15 min before starting sample collection and hence was present during the whole assay including $S_{1}$ and $S_{2}$. When present during $S_{1}$ and $S_{2}$, none of the modifiers significantly altered $(p>0.05)$ the $S_{2} / S_{1}$ ratio as compared to the $\mathrm{S}_{2} / \mathrm{S}_{1}$ ratio obtained in the absence of the modifiers $(0.81 \pm$ $0.03, \mathrm{n}=8)$. None of the drugs changed significantly $(\mathrm{p}>0.05)$ basal tritium outflow (see fig. 1, 3, 4).

\section{Materials and Solutions}

8-Bromoadenosine-3',5'-cyclic monophosphate sodium salt (8-Br-cAMP), choline chloride, 1,9-dideoxyforskolin (1,9-ddFSK), forskolin (FSK), hemicholinium-3, (4-hydroxy-2-butynyl)-1-trimethylammonium- $m$-chlorocarbanilate chloride (McN-A-343), nifedipine, pirenzepine dihydrochloride (Sigma, St. Louis, Mo., USA); chelerythrine (CHL), 11-[2-1[(diethylamino)methyl-1- 


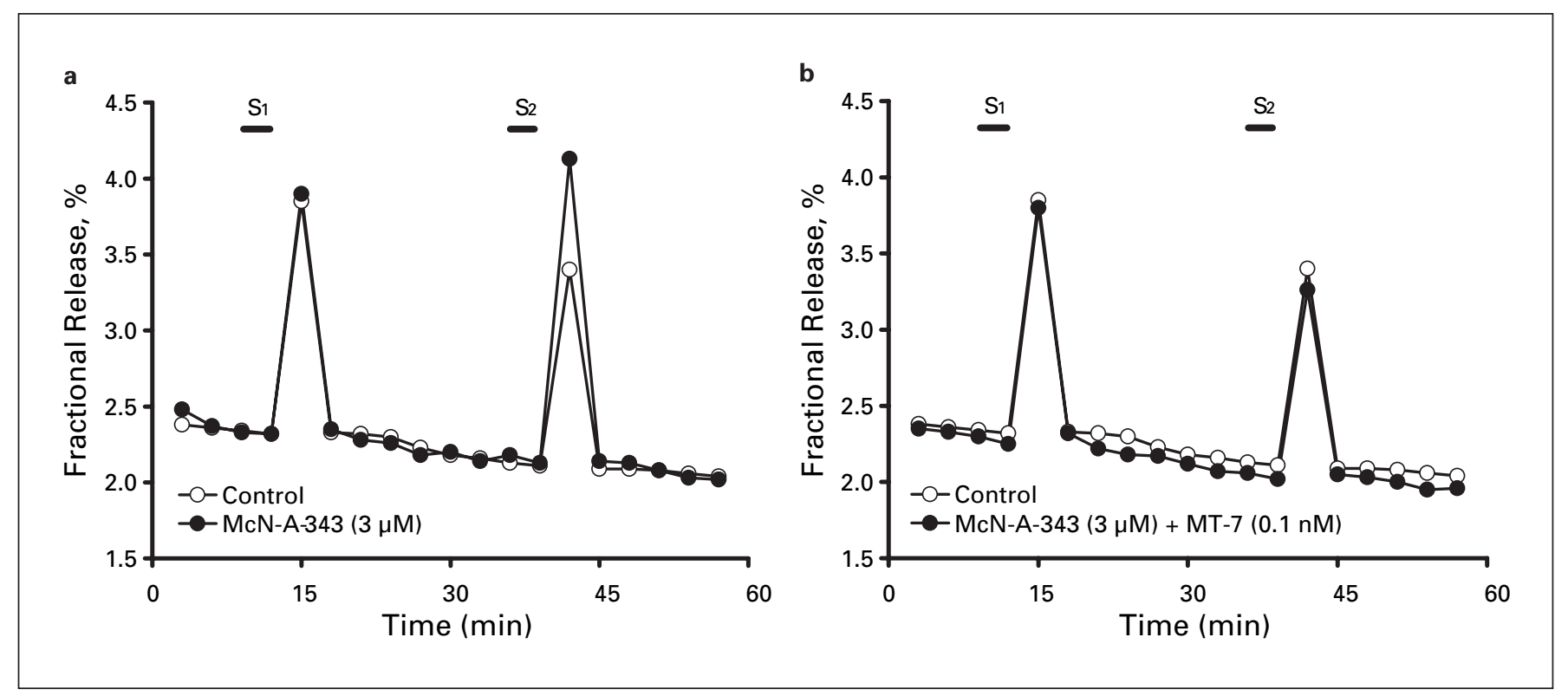

Fig. 1. Role of the selective muscarinic $M_{1}$ receptor antagonist, MT-7 $(0.1 \mathrm{n} M)$, on McN-A-343 (3 $\mu M)$-induced facilitation of evoked $\left[{ }^{3} \mathrm{H}\right] \mathrm{ACh}$ release from motor nerve terminals. Shown is the time course of tritium outflow from phrenic nerve terminals taken from typical experiments in the absence (Control, open circles) and in the presence of $\mathrm{McN}-\mathrm{A}-343(3 \mu M)$, used either (a) alone or (b) after pretreatment with MT-7 $(0.1 \mathrm{n} M)$. Tritium outflow (ordinates) is expressed as a percentage of the total radioactivity present

piperidinyl]-acetyl]-5,11-dihydro-6H-pyrido[2,3-b] [1,4]benzodiazepine-6-one (AF-DX 116), phorbol 12-myristate 13-acetate (PMA),4-(2-[7-amino-2-(2-furyl)(1,2,4)-triazolo(2,3-a)1,3,5]triazin5yl-aminoethyl)phenol (ZM241385), 4-(3'-cyclopentyloxy-4'-methoxyphenyl)-2-pyrrolidone (4-RS) (rolipram, ROL) (Tocris Cookson Inc., UK); 2-(4-[2-p-carboxyethylphenylamino]-5'-N-ethylcarboxamido adenosine (CGS21680C), Rp-adenosine 3',5'-cyclic monophosphothioate triethylamine (Rp-cAMPS) (Research Biochemicals, Natick, Mass., USA); muscarinic toxin 7 (MT-7) (Peptide Institute Inc., Japan); [methyl- $\left.{ }^{3} \mathrm{H}\right]$ choline chloride (ethanol solution, $80 \mathrm{Ci} \mathrm{mmol}^{-1}$ ) (Amersham, UK); ROL (4-(3'-cyclopentyloxy-4'-methoxyphenyl)-2-pyrrolidone) was a gift from Schering AG (Berlin, Germany). All other reagents were of the highest purity available. Stock solutions of AF-DX 116, CGS21680C, PMA, ZM241385, ROL, 1,9-ddFSK were prepared in dimethylsulfoxide (DMSO), and FSK was prepared in absolute ethanol. Nifedipine was made up in a 10-m $M$ stock solution in ethanol, which was kept protected from the light to prevent photodecomposition. Other drugs were prepared in distilled water. All stock solutions were stored as frozen aliquots at $-20^{\circ} \mathrm{C}$. Dilutions of these stock solutions were made daily and appropriate solvent controls were done. No statistically significant differences between control experiments, made in the absence or in the presence of the solvents at the maximal concentrations used $\left(0.5 \% \mathrm{vv}^{-1}\right)$, were observed. The $\mathrm{pH}$ of the superfusion solution did not change following addition of the drugs at the maximum concentrations applied to the preparations. in the tissue at the beginning of the collection period and was measured in samples collected every $3 \mathrm{~min} .\left[{ }^{3} \mathrm{H}\right] \mathrm{ACh}$ release was elicited by stimulating the phrenic nerve trunk with 750 pulses delivered with a frequency of $5 \mathrm{~Hz}$ at the indicated times $\left(\mathrm{S}_{1}\right.$ and $\left.\mathrm{S}_{2}\right)$. McN-A-343 $(3 \mu M)$ was applied 15 min before $\mathrm{S}_{2}$; MT-7 $(0.1 \mathrm{n} M)$ was present throughout the assay including $S_{1}$ and $S_{2}$. None of the drugs changed spontaneous tritium outflow.

\section{Statistics}

The data are expressed as mean \pm SEM, with $n$ indicating the number of experiments. Statistical analysis of data was carried out using paired or unpaired Student's t test or one-way analysis of variance (ANOVA) followed by Dunnett's modified t test. $p$ values at $<0.05$ were considered to represent significant differences.

\section{Results}

Recently we have demonstrated that the muscarinic $\mathrm{M}_{1}$ receptor agonist, McN-A-343 (1-30 $\mu M$ ), concentration-dependently increased the release of $\left[{ }^{3} \mathrm{H}\right] \mathrm{ACh}$ from stimulated $(5 \mathrm{~Hz}$ frequency, 750 pulses of $0.04 \mathrm{~ms}$ duration) phrenic motor nerve terminals [2]. Figure 1 shows that McN-A-343 $(3 \mu M)$-induced enhancement (48 $\pm 6 \%$, $\mathrm{n}=11)$ of $\left[{ }^{3} \mathrm{H}\right] \mathrm{ACh}$ release was prevented by the muscarinic toxin isolated from the venom of the green mamba (Dendroaspis augusticeps), MT-7 (0.1 nM), which exhibits high subtype selectivity for $\mathrm{M}_{1}\left(\mathrm{pK}_{\mathrm{B}} \sim 9.8\right)$ receptors [see 4]. Under the same experimental conditions, the muscarinic $\mathrm{M}_{2}$ receptor antagonist, AF-DX $116(10 \mathrm{n} M)$, failed 


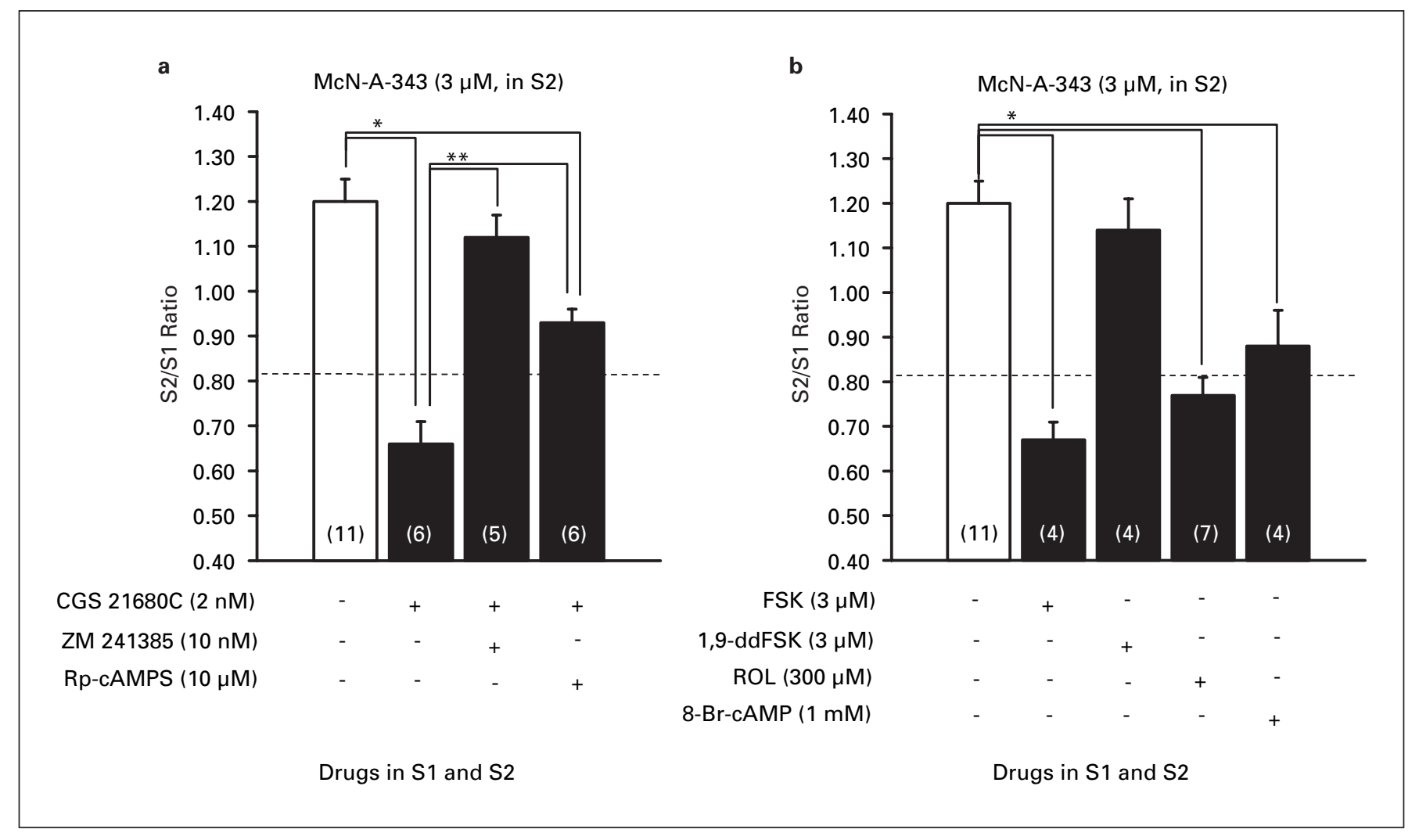

Fig. 2a, b. Agonist-induced adenosine $A_{2 A}$ receptors activation suppresses the facilitatory effect of McN-A-343 (3 $\mu M)$ on evoked $\left[{ }^{3} \mathrm{H}\right] \mathrm{ACh}$ release from motor nerve terminals through a mechanism positively coupled to the adenylate cyclase/cyclic AMP pathway. McN-A-343 $(3 \mu M)$ was applied 15 min before $\mathrm{S}_{2}$. CGS21680C $(2 \mathrm{n} M)$ with or without ZM241385 $(10 \mathrm{n} M)$ or Rp-cAMPS $(10 \mu M)$, FSK $(3 \mu M), 1,9-d d F S K(3 \mu M)$, ROL $(300 \mu M)$, and 8-Br-cAMP $(1 \mathrm{~m} M)$, were present throughout the assay including $\mathrm{S}_{1}$ and $\mathrm{S}_{2}$. The $\mathrm{S}_{2} / \mathrm{S}_{1}$ ratios obtained under these conditions were not statistically

to antagonize McN-A-343 (3 $\mu M$ ) facilitation (data not shown) [cf. 2].

The ability of McN-A-343 $(3 \mu M)$ to increase $\left[{ }^{3} \mathrm{H}\right] \mathrm{ACh}$ release was blunted upon activating facilitatory adenosine $\mathrm{A}_{2 \mathrm{~A}}$ receptors on phrenic motor nerve terminals with CGS21680C ( $2 \mathrm{n} M$, applied during the whole assay including $\mathrm{S}_{1}$ and $\mathrm{S}_{2}$ ) (fig. 2a). McN-A-343 (3 $\mu M$ )-induced facilitation was restored when CGS21680C $(2 \mathrm{nM})$ was applied together with the selective $\mathrm{A}_{2 \mathrm{~A}}$ receptor antagonist, ZM241385 (10 nM). Inhibition of $\mathrm{M}_{1}$-induced facilitation by CGS21680C ( $2 \mathrm{nM}$ ) was partially recovered when the $\mathrm{A}_{2 \mathrm{~A}}$ receptor agonist was co-applied with the cyclic AMP antagonist Rp-cAMPS $(10 \mu M)$ (fig. 2a). Furthermore, stimulation of the adenylate cyclase/cyclic AMP pathway by FSK ( $3 \mu M$, an adenylate cyclase acti- different from the ratio obtained in control experiments (without any drug during $S_{1}$ and $S_{2}$ ) (dashed horizontal line, for values see Materials and Methods). The ordinates represent evoked tritium outflow expressed by $S_{2} / S_{1}$ ratios. Each column represents pooled data from an $n$ number of experiments shown in parentheses. The vertical bars represent SEM. ${ }^{*} * * \mathrm{p}<0.05$ (one-way ANOVA followed by Dunnett's modified $t$ test) when compared with the effect of McN-A-343 alone or in the presence of CGS21680C, respectively. vator), ROL (300 $\mu M$, a non-xanthine inhibitor of phosphodiesterase) and 8-Br-cAMP (1 $\mathrm{m} M$, a cell-permeant cyclic AMP analogue) mimicked the CGS21680C ( $2 \mathrm{nM})$ blockade (fig. 2b). The effect of FSK seems to be specific, since 1 ,9-ddFSK $(3 \mu M)$, which is a FSK analogue inactive on adenylate cyclase [17], did not significantly ( $p>$ 0.05 ) change the enhancing effect of McN-A-343 (3 $\mu M)$ on $\left[{ }^{3} \mathrm{H}\right] \mathrm{ACh}$ release (fig. $2 \mathrm{~b}$ ). Taken together, these results indicate that occlusion of $\mathrm{M}_{1}$ facilitation by the $\mathrm{A}_{2 \mathrm{~A}}$ agonist requires activation of the adenylate cyclase/cyclic AMP transduction system.

Figure 3 shows that, on the other hand, McN-A-343 ( $3 \mu M$, applied during the whole assay including $\mathrm{S}_{1}$ and $\mathrm{S}_{2}$ ) suppressed the ability of CGS21680C (2 nM, $24 \pm$ $6 \%, \mathrm{n}=5$ ) to facilitate $\left[{ }^{3} \mathrm{H}\right] \mathrm{ACh}$ release, indicating that 
adenosine $A_{2 A}$ receptor activity is restrained when the $M_{1}$ receptor is operative. The way muscarinic $M_{1}$ receptor decreases adenosine $\mathrm{A}_{2 \mathrm{~A}}$ facilitation may involve PKC activation. This hypothesis was considered because application of the selective PKC inhibitor CHL together with McN-A-343 (3 $\mu M)$ restored CGS21680C (2 nM) facilitation (fig. 3a). It is worth noting that CHL was applied during the whole assay including $S_{1}$ and $S_{2}$ in a concentration $(5 \mu M)$ high enough to prevent the ability of both the PKC activator, PMA $(10 \mu M, 27 \pm 7 \%, \mathrm{n}=4)$, and McN-A-343 $(10 \mu M, 72 \pm 12 \%, \mathrm{n}=4)$ to facilitate $\left[{ }^{3} \mathrm{H}\right] \mathrm{ACh}$ release (fig. 3b), without significantly affecting the facilitatory action of CGS21680C (2 nM) (fig. 3a).

Whilst in the process of investigating the negative interaction between facilitatory muscarinic $\mathrm{M}_{1}$ and adenosine $A_{2 A}$ receptors, we made the incidental observation that inhibition of PKA activity with Rp-cAMPS $(10 \mu M)$ reduced the ability of McN-A-343 $(3 \mu M)$ to increase $\left[{ }^{3} \mathrm{H}\right] \mathrm{ACh}$ release, in parallel to the expected blockade of the PKA-mediated facilitatory effect of CGS21680C $(2 \mathrm{nM})$ (fig. 4a). Figure 4a also shows that blockade of $\mathrm{Ca}_{\mathrm{v}} 1$ (L-type) channels with nifedipine $(1 \mu M)$ mimicked Rp-cAMPS $(10 \mu M)$ suppression of McN-A-343 (3 $\mu M)$ and CGS21680C (2 $\mathrm{n} M)$-induced facilitation of evoked

Fig. 3. Muscarinic $\mathrm{M}_{1}$ receptor activation suppresses the ability of CGS21680C to enhance $\left[{ }^{3} \mathrm{H}\right] \mathrm{ACh}$ release from motor nerve terminals by a mechanism involving PKC activity. a CGS21680C ( $2 \mathrm{nM})$ was applied $15 \mathrm{~min}$ before $\mathrm{S}_{2}$, whereas McN-A-343 $(3 \mu M)$ with or without CHL $(5 \mu M)$ was present throughout the assay including $S_{1}$ and $S_{2}$. The $S_{2} / S_{1}$ ratios obtained under these conditions were not statistically different from the ratio obtained in control experiments (without any drug during $\mathrm{S}_{1}$ and $\mathrm{S}_{2}$ ) (dashed horizontal line, for values see Materials and Methods). The ordinates represent evoked tritium outflow expressed by $\mathrm{S}_{2} / \mathrm{S}_{1}$ ratios. Each column represents pooled data from an $n$ number of experiments shown in parentheses. The vertical bars represent SEM. *p $<0.05$ (one-way ANOVA followed by Dunnett's modified t test) when compared with the effect of CGS21680C alone. b Shown is the time course of tritium outflow from phrenic nerve terminals taken from typical experiments in the absence (Control, open circles) and in the presence of McN-A-343 (10 $\mu M)$, used either alone (closed circles) or after pretreatment with CHL ( $5 \mu M$, closed squares). Tritium outflow (ordinates) is expressed as a percentage of the total radioactivity present in the tissue at the beginning of the collection period and was measured in samples collected every $3 \mathrm{~min} .\left[{ }^{3} \mathrm{H}\right] \mathrm{ACh}$ release was elicited by stimulating the phrenic nerve trunk with 750 pulses delivered with a frequency of $5 \mathrm{~Hz}$ at the indicated times $\left(\mathrm{S}_{1}\right.$ and $\left.\mathrm{S}_{2}\right)$. McN-A-343 $(3 \mu M)$ was applied 15 min before $\mathrm{S}_{2}$, whereas CHL $(5 \mu M)$ was present throughout the assay including $\mathrm{S}_{1}$ and $\mathrm{S}_{2}$. $\left[{ }^{3} \mathrm{H}\right] \mathrm{ACh}$ release. This prompted us to investigate if the facilitatory effects of $\mathrm{M}_{1}$ and $\mathrm{A}_{2 \mathrm{~A}}$ receptor agonists were surmountable and if blockade of a common signal target such as the $\mathrm{Ca}_{\mathrm{v}} 1$ (L-type) channel could occlude their effects. Incubation of motor nerve terminals $15 \mathrm{~min}$ before $\mathrm{S}_{2}$ with McN-A-343 (3 $\left.\mu M\right)$ plus CGS21680C ( $\left.2 \mathrm{n} M\right)$ did not enhance further the release of $\left[{ }^{3} \mathrm{H}\right] \mathrm{ACh}$ over that seen with the more active agonist, McN-A-343 $(3 \mu M)$, alone (fig. $4 \mathrm{~b}, \mathrm{c}$ ). Thus, if both drugs were acting on separate coincidental signalling pathways, then combination of $\mathrm{M}_{1}$ and $\mathrm{A}_{2 \mathrm{~A}}$ receptor agonists should have increased further a $\quad$ CGS21680C (2 nM, in S2)

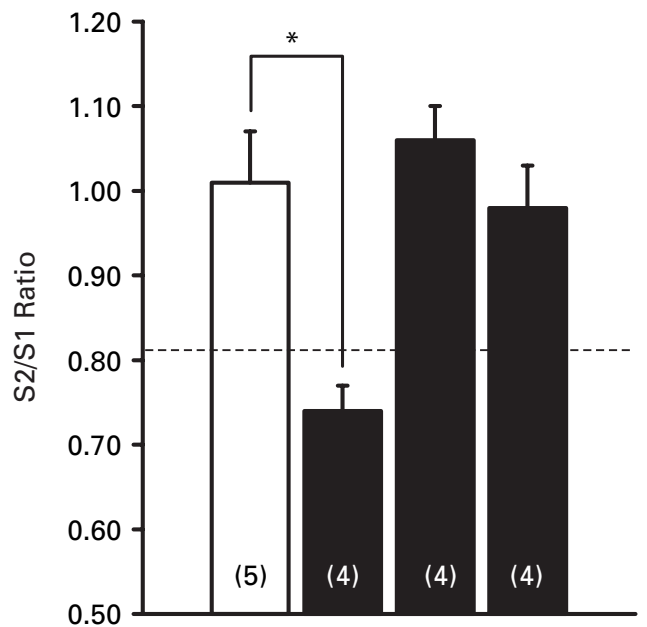

$\mathrm{McN}-\mathrm{A}-343(3 \mu \mathrm{M})$ $\mathrm{CHL}(5 \mu \mathrm{M})$
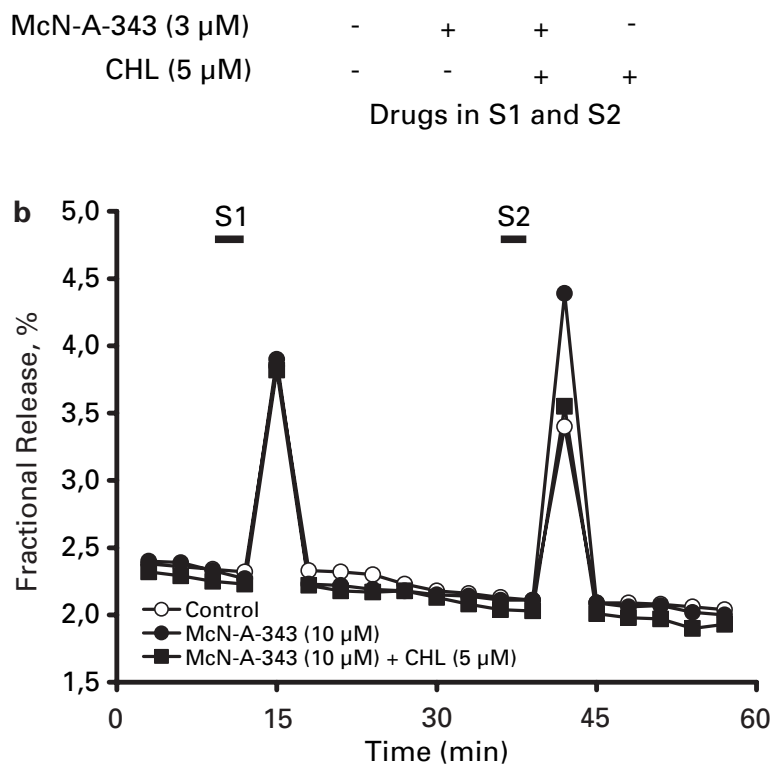
$\left[{ }^{3} \mathrm{H}\right] \mathrm{ACh}$ release. A possible antagonistic interaction between the two receptors can also be ruled out, since maximum facilitation reached in the presence of both agonists was equivalent to that seen with the more effective compound. Moreover, nifedipine ( $1 \mu M$, applied during the whole assay including $S_{1}$ and $S_{2}$ ) abolished the facilitatory effect caused by synchronous application of McN-A$343(3 \mu M)$ plus CGS21680C ( $2 \mathrm{n} M)$ before $\mathrm{S}_{2}$ (fig. $4 \mathrm{c}$ ).

Because $\mathrm{Ca}_{\mathrm{v}} 1$ (L-type) channels do not ordinarily participate in the release process [6-8], we investigated if $\mathrm{Ca}^{2+}$ influx through these channels could be unmasked upon activating facilitatory muscarinic $\mathrm{M}_{1}$ and adenosine $A_{2 A}$ receptors [see e.g. 9, 10]. Nifedipine, used in a concentration $(1 \mu M)$ considered specific for blocking $\mathrm{Ca}_{\mathrm{v}} 1$ (L-type) channels [18], inhibited the release of $\left[{ }^{3} \mathrm{H}\right] \mathrm{ACh}$ only in the presence of McN-A-343 $(3 \mu M)$ and/ or CGS21680C ( $2 \mathrm{nM})$, having no significant effect under non-facilitatory conditions (fig. 5). The inhibitory action of nifedipine $(1 \mu M)$ resulting from co-application of McN-A-343 $(3 \mu M)$ plus CGS21680C $(2 \mathrm{n} M)$ had a similar magnitude to that observed when each drug was used alone (fig. 5). Thus, mutual exclusion of muscarinic $\mathrm{M}_{1}$ and adenosine $\mathrm{A}_{2 \mathrm{~A}}$ receptors is in keeping with the hy-

Fig. 4. Activation of facilitatory muscarinic $M_{1}$ and adenosine $A_{2 A}$ receptors were both prevented by blocking PKA activity and $\mathrm{Ca}^{2+}$ influx through $\mathrm{Ca}_{\mathrm{v}} 1$ (L-type) channels with Rp-cAMPS $(10 \mu M)$ and nifedipine $(1 \mu M)$, respectively. a McN-A-343 $(3 \mu M)$ or CGS21680C ( $2 \mathrm{nM})$ were applied $15 \mathrm{~min}$ before $\mathrm{S}_{2}$; in the experiments using Rp-cAMPS $(10 \mu M)$ or nifedipine $(1 \mu M)$, these drugs were present throughout the assay including $S_{1}$ and $S_{2}$. The $S_{2} / S_{1}$ ratios obtained under these conditions were not statistically different from the ratio obtained in control experiments (without any drug during $S_{1}$ and $S_{2}$ ) (dashed horizontal line, for values see Materials and Methods). The ordinates represent evoked tritium outflow expressed by $S_{2} / S_{1}$ ratios. Each column represents pooled data from 4 to 11 experiments. The vertical bars represent SEM. ${ }^{*} \mathrm{p}<$ 0.05 (one-way ANOVA followed by Dunnett's modified t-test) when compared with the facilitatory effects of $\mathrm{McN}-\mathrm{A}-343$ or CGS21680C alone. b, c Shown is the time course of tritium outflow from phrenic nerve terminals taken from typical experiments in the absence (Control, open circles) and in the presence of McN-A-343 ( $3 \mu M$, closed circles), CGS21680C ( $2 \mathrm{n} M$, open squares) and $\mathrm{McN}$ A-343 $(3 \mu M)$ plus CGS21680C (2 $\mathrm{n} M$ ) (closed squares), applied 15 min before $\mathrm{S}_{2}$. In the experiments using nifedipine ( $1 \mu M$, open squares in c), this drug was present throughout the assay including $\mathrm{S}_{1}$ and $\mathrm{S}_{2}$. Tritium outflow (ordinates) is expressed as a percentage of the total radioactivity present in the tissue at the beginning of the collection period and was measured in samples collected every $3 \mathrm{~min} .\left[{ }^{3} \mathrm{H}\right] \mathrm{ACh}$ release was elicited by stimulating the phrenic nerve trunk with 750 pulses delivered with a frequency of $5 \mathrm{~Hz}$ at the indicated times $\left(\mathrm{S}_{1}\right.$ and $\left.\mathrm{S}_{2}\right)$.

PKA and $\mathrm{Ca}_{\mathrm{v}} 1$ Channels Are Common Targets to $\mathrm{A}_{2 \mathrm{~A}}$ and $\mathrm{M}_{1}$ Receptors
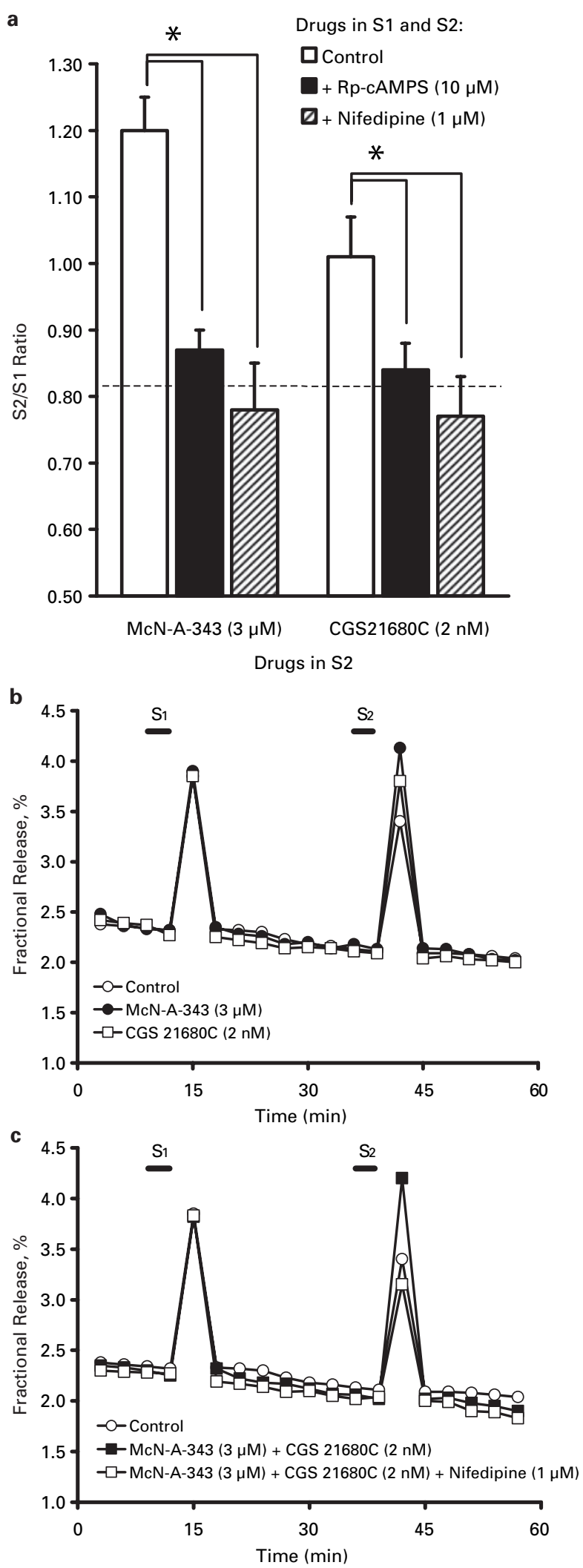


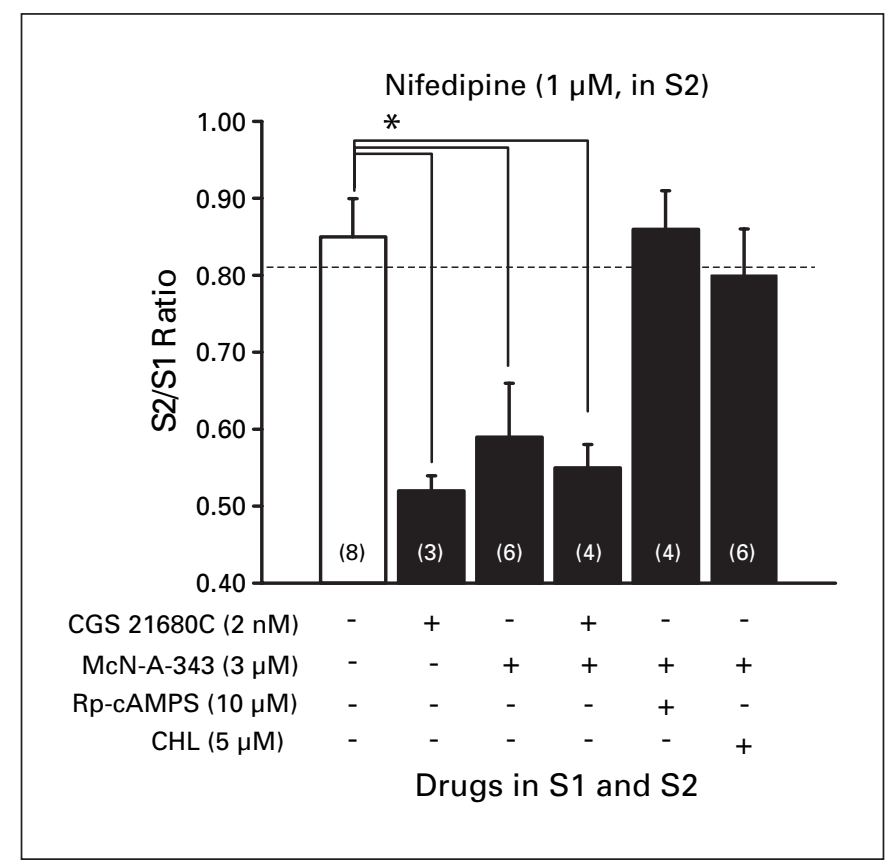

Fig. 5. Activation of facilitatory muscarinic $M_{1}$ and adenosine $A_{2 A}$ receptors trigger $\mathrm{Ca}^{2+}$ influx through nifedipine-sensitive channels: role of PKA and PKC activity. Nifedipine $(1 \mu M)$ was applied 15 min before $\mathrm{S}_{2}$. CGS21680C (2 $\left.\mathrm{n} M\right)$, McN-A-343 (3 $\left.\mu M\right), \mathrm{Rp}-$ cAMPS $(10 \mu M)$, and CHL $(5 \mu M)$ were present throughout the assay including $S_{1}$ and $S_{2}$. The $S_{2} / S_{1}$ ratios obtained under these conditions were not statistically different from the ratio obtained in control experiments (without any drug during $\mathrm{S}_{1}$ and $\mathrm{S}_{2}$ ) (dashed horizontal line, for values see Materials and Methods). The ordinates represent evoked tritium outflow expressed by $S_{2} / S_{1}$ ratios. Each column represents pooled data from an $n$ number of experiments shown in parentheses. The vertical bars represent SEM. $* \mathrm{p}<0.05$ (one-way ANOVA followed by Dunnett's modified $t$ test) when compared with the effect of nifedipine alone.

pothesis that both receptors share a common signalling pathway to facilitate $\left[{ }^{3} \mathrm{H}\right] \mathrm{ACh}$ release, which may ultimately trigger $\mathrm{Ca}^{2+}$ influx through physiologically 'silent' $\mathrm{Ca}_{\mathrm{v}} 1$ (L-type) channels.

Inhibition of PKA or PKC respectively with $\mathrm{Rp}$ cAMPS $(10 \mu M)$ and CHL $(5 \mu M)$ prevented the ability of nifedipine $(1 \mu M)$ to decrease evoked $\left[{ }^{3} \mathrm{H}\right] \mathrm{ACh}$ release in the presence of McN-A-343 (3 $\mu M$ ) (fig. 5). These results demonstrate that $\mathrm{M}_{1}$-induced $\mathrm{Ca}^{2+}$ influx through $\mathrm{Ca}_{\mathrm{v}} 1$ (L-type) channels requires parallel activation of both PKA and PKC enzymes. Since Rp-cAMPS (10 $\mu M)$ attenuated the stimulatory effect of the PKC activator, PMA $(10 \mu M, 27 \pm 9 \%, \mathrm{n}=4)$, but CHL $(5 \mu M)$ was unable to affect the facilitatory action of the enzymatically stable cyclic AMP analogue, 8-bromo-cyclic AMP ( $1 \mathrm{~m} M$, $30 \pm 3 \%, n=4$ ) (fig. 6), data suggest that the involvement of PKA may be secondary to PKC activation.

\section{Discussion}

$\mathrm{ACh}$, in addition to its stimulatory action on muscle fibers, also acts pre-synaptically to regulate its own release at the rat neuromuscular junction [see e.g. 19]. Neuronal nicotinic autoreceptors containing $\alpha 3 \beta 2$ subunits [20] mediate a short-term positive feedback mechanism, which is terminated by rapid autodesensitization $[21,22]$. Dual modulation (facilitation and inhibition) of ACh release has been demonstrated using muscarinic receptor agonists and antagonists [2, 23, 24]. Controversy on the predominant role of co-expressed muscarinic $\mathrm{M}_{1}$-facilitatory and $\mathrm{M}_{2}$-inhibitory receptors in motoneurons arose from differences in their pharmacology profile and stimulus activation mode [for review, see 3]. Consensus in data interpretation is challenged if variations on the release of transmitters and other neuromodulators (e.g. adenosine) during repetitive nerve stimuli are not taken into account [15]. The predominance of muscarinic $\mathrm{M}_{1}$ autofacilitation coincided with the appearance of small amounts of endogenous adenosine activating inhibitory $A_{1}$ receptors, which did not interfere with the $M_{1}$ receptor function [2]. Conversely, upon increasing the amount of adenosine generated at the synapse to levels capable of activating facilitatory $A_{2 A}$ receptors, the $M_{1}$-positive feedback mechanism is weakened and the muscarinic neuromodulatory control is shifted towards $\mathrm{M}_{2}$ inhibition. Thus, co-expression of different subtypes of receptors mediating functional responses result in confusing pharmacological profiles, which might depend on potential interactions at the transduction system level. In the present work we have, for the first time, systematically examined the transduction mechanism involved in the cross-talk between facilitatory $\mathrm{M}_{1}$ and $\mathrm{A}_{2 \mathrm{~A}}$ receptors in the rat neuromuscular junction.

Interactions between G-protein-coupled receptors may occur at the level of receptors, G-proteins, effectors activation or second messengers [for review, see 14]. Most frequently, adenosine $\mathrm{A}_{2 \mathrm{~A}}$ receptors interact with other pre-synaptic receptors by coupling to the adenylate cyclase/cyclic AMP system [1]. This pathway seemed a good candidate to the molecular mechanism responsible for the occlusion of the $M_{1}$ receptor activity. Our findings strongly support this hypothesis, as pre-treatment with the cyclic AMP antagonist, Rp-cAMPS, partially reversed 
the impairment of McN-A-343-induced facilitation of $\left[{ }^{3} \mathrm{H}\right] \mathrm{ACh}$ release in the presence of CGS21680C. Moreover, stimulators of the adenylate cyclase/cyclic AMP pathway, like FSK, ROL, and 8-Br-cAMP, mimicked the ability of CGS21680C to decrease $\mathrm{M}_{1}$ facilitation. Although PKC has also been reported to operate cross-talk involving $\mathrm{A}_{2 \mathrm{~A}}$ receptors in the central nervous system [25, 26], our findings do not support this possibility as the inhibition of PKC activity by CHL did not modify the facilitatory effect of CGS21680C (see fig. 3), even though CHL has been used in a concentration $(5 \mu M)$ that blocked the ability of the active phorbol ester, PMA, to increase the release of $\left[{ }^{3} \mathrm{H}\right] \mathrm{ACh}$. The incapacity of CHL to attenuate CGS21680C facilitation also rules out interference of the PKC inhibitor with the adenosine $\mathrm{A}_{2 \mathrm{~A}}$ receptor [27]. Conversely, CHL prevented McN-A-343-induced facilitation of $\left[{ }^{3} \mathrm{H}\right] \mathrm{ACh}$ release and restored the ability of CGS21680C to enhance transmitter release in the presence of the $\mathrm{M}_{1}$-receptor agonist. This is in keeping with data showing that the muscarinic $\mathrm{M}_{1}$ receptor couples via $\mathrm{G}_{\mathrm{q} / 11}$ proteins to phospholipase $\mathrm{C}$ activation and PKC stimulation by diacylglycerol $[4,13]$.

Fig. 6. $\mathrm{PKC}$-mediated facilitation of $\left[{ }^{3} \mathrm{H}\right] \mathrm{ACh}$ release from motor nerve terminals requires secondary activation of PKA. a PMA $(10 \mu M)$ and 8-Br-cAMP $(1 \mathrm{mM})$ were applied $15 \mathrm{~min}$ before $\mathrm{S}_{2}$. Rp-cAMPS $(10 \mu M)$ and CHL $(5 \mu M)$ were present throughout the assay, including $S_{1}$ and $S_{2}$. The $S_{2} / S_{1}$ ratios obtained under these conditions were not statistically different from the ratio obtained in control experiments (without any drug during $\mathrm{S}_{1}$ and $\mathrm{S}_{2}$ ) (dashed horizontal line, for values see Materials and Methods). The ordinates represent evoked tritium outflow expressed by $\mathrm{S}_{2} / \mathrm{S}_{1}$ ratios. Each column represents pooled data from 4 to 5 experiments. The vertical bars represent SEM. * $<<0.05$ (one-way ANOVA followed by Dunnett's modified $t$ test) when compared with the effects of PMA or 8-Br-cAMP alone. b Shown is a schematic representation of intracellular second messengers involved in the cross-talk between facilitatory adenosine $A_{2 A}$ and muscarinic $M_{1}$ receptors on motor nerve terminals. Stimulation of $\mathrm{A}_{2 \mathrm{~A}}$ receptors leads to activation of adenylate cyclase (AC) and production of cyclic AMP (cAMP), thereby increasing PKA activity. Activated $\mathrm{M}_{1}$ receptors stimulate PLC to release inositol $(1,4,5)$ trisphosphate $\left(\mathrm{IP}_{3}\right)$ and diacylglycerol (DAG), which cause the release of intracellular $\mathrm{Ca}^{2+}$ and activate PKC, respectively. Secondary stimulation of PKA by $\mathrm{M}_{1}$-induced $\mathrm{PKC}$ activation is thought to precede augmentation of $\mathrm{Ca}^{2+}$ influx through $\mathrm{Ca}_{\mathrm{v}} 1$ (L-type) channels and facilitation of $\mathrm{ACh}$ release. Therefore, coupling of $\mathrm{M}_{1}$ and $\mathrm{A}_{2 \mathrm{~A}}$ receptors to a common pathway involving PKA activation and $\mathrm{Ca}^{2+}$ recruitment through $\mathrm{Ca}_{\mathrm{v}} 1$ (L-type) channels might explain the negative interplay between these receptors to control neurotransmitter release at the rat motor endplate.

PKA and $\mathrm{Ca}_{\mathrm{v}} 1$ Channels Are Common Targets to $\mathrm{A}_{2 \mathrm{~A}}$ and $\mathrm{M}_{1}$ Receptors
Depending on the cell type, multiple mechanisms have been suggested to explain the negative interplay between adenylate cyclase and PLC systems. Most evidence seems to suggest that the modulation of $\mathrm{G}_{\mathrm{q}}$-mediated responses is due to downstream activation of PKA [14]. On the one

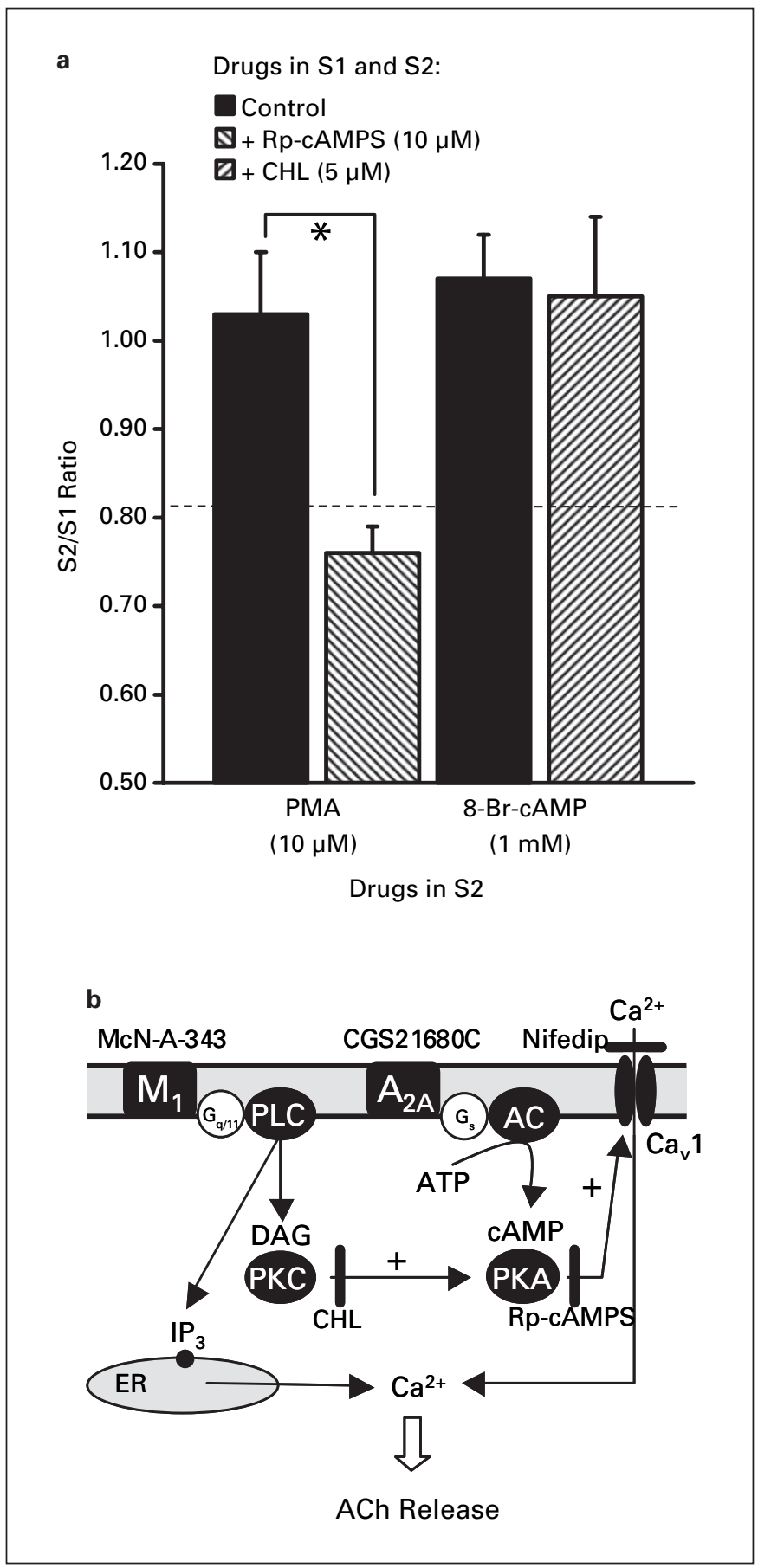

Neurosignals 2005;14:262-272 
hand, PKA has been shown to cause phosphorylation and deactivation of PLC $[28,29]$. If this were the case at the rat motor endplate, inhibition of PKA by Rp-cAMPS would increase, rather than decrease, the facilitatory action of McN-A-343 (fig. 4a). On the other hand, PKA may phosphorylate $\mathrm{IP}_{3}$ receptors, leading to an increase in their activity [30]. This seems also very unlikely, as the effect of McN-A-343 was suppressed by the $\mathrm{A}_{2 \mathrm{~A}}$ agonist, CGS21680C, as well as by stimulators of the cyclic AMP system, FSK, ROL, and 8-Br-cAMP. Functional weakening of the adenosine $\mathrm{A}_{2 \mathrm{~A}}$ receptor may also result from inhibition of adenylate cyclase activity operated by PKC phosphorylation when the $\mathrm{M}_{1}$ receptor is activated. This hypothesis agrees with the general idea of PKC operating the uncoupling of receptors from the stimulation of adenylate cyclase [31], and is consistent with the restoration of CGS21680C facilitation when McN-A-343 was co-applied with CHL. The participation of PKC in the crosstalk operated by muscarinic $\mathrm{M}_{1}$ receptors is further strengthen as active phorbol esters (e.g. PMA) mimicked the ability of McN-A-343 to decrease facilitation of ACh release caused by ligands capable of enhancing intracellular cyclic AMP, like FSK and ROL (unpubl. observations). PKC specifically inhibits adenylate cyclase type VI activity through protein phosphorylation; via this mechanism PKC causes desensitization of adenosine $\mathrm{A}_{2 \mathrm{~A}}$ receptors in rat PC12 cells [32].

Pre-synaptic PKA and PKC activation facilitate neurotransmitter release in various regions of the nervous system [see 5, 33, 34]. Although the exact mechanism through which receptors stimulating PKC and PKA regulate transmitter release is controversial, the observation that the facilitatory actions of adenosine $\mathrm{A}_{2 \mathrm{~A}}$ and muscarinic $M_{1}$ receptors are mutually exclusive led to the hypothesis that both signalling pathways could share a common target. This is feasible based on several common actions of PKA and PKC. One possibility includes phosphorylation of Rab3A (a small GTP-binding protein attached to synaptic vesicles) and of its associated effectors (like rabphilin), which have been associated both with the trafficking of synaptic vesicles and with an effect on a late stage of the $\mathrm{Ca}^{2+}$-dependent neurotransmitter release process [35]. Given that synapses from Rab3A-knockout mice exhibit profound synaptic depression when stimulated repetitively, it is tempting to speculate that proteins of the Rab family may be a substrate for the facilitatory action of both $\mathrm{M}_{1}$ and $\mathrm{A}_{2 \mathrm{~A}}$ receptors at the motor endplate. Further studies using deletion mutants are needed to investigate the functional significance of Rab phosphorylation in the cross-talk between $\mathrm{M}_{1}$ and $\mathrm{A}_{2 \mathrm{~A}}$ recep- tors. Another possibility is a dramatic increase in $\mathrm{Ca}^{2+}$ influx into nerve terminals through phosphorylated $\mathrm{Ca}_{\mathrm{v}} 1$ (L-type) voltage-gated channels yielding to the enhancement of transmitter release [11-13]. We addressed this question by testing the effects resulting from co-application of McN-A-343 and CGS21680C after pretreatment with the $\mathrm{Ca}_{\mathrm{v}} 1$ (L-type) channel blocker, nifedipine. Prior application of nifedipine suppressed facilitation of $\mathrm{ACh}$ release due to co-activation of muscarinic $\mathrm{M}_{1}$ and adenosine $A_{2 A}$ receptors, confirming our suspicion that parallel PKC and PKA stimulations may ultimately converge to $\mathrm{Ca}^{2+}$ influx via facilitatory $\mathrm{Ca}_{\mathrm{v}} 1$ (L-type) channels. Moreover, data also suggest that McN-A-343 may enhance $\mathrm{Ca}^{2+}$ influx via $\mathrm{Ca}_{\mathrm{v}} 1$ (L-type) channels $[9,13]$ in a similar manner to that caused upon incubating the rat motor endplate with CGS21680C [10]. Our findings are consistent with knockout studies using mouse models demonstrating that $\mathrm{M}_{1}$ receptors couple to a diffusible second messenger pathway to interact with the activity of $\mathrm{Ca}_{\mathrm{v}} 1$ (Ltype) channels [36].

Another major strength of the present work is the demonstration that the mechanism by which muscarinic $\mathrm{M}_{1}$ receptor mobilizes $\mathrm{Ca}^{2+}$ through 'quiescent' $\mathrm{Ca}_{\mathrm{v}} 1$ (L-type) channels requires concomitant activation of both PKC and PKA enzymes, whereas the $\mathrm{A}_{2 \mathrm{~A}}$-receptor-mediated action occurs through stimulation of PKA without needing PKC activity (see above). Blockade of McN-A-343induced enhancement of nifedipine inhibition by $\mathrm{CHL}$ and by Rp-cAMPS is consistent with that hypothesis. Although less frequently, activation of the cyclic AMP pathway by $\mathrm{M}_{1}$ receptors has been documented in vertebrate preparations [37-39]. Moreover, activation of PKA seems to operate facilitation of $\left[{ }^{3} \mathrm{H}\right] \mathrm{ACh}$ release independently of PKC activity, as CHL was unable to modify the facilitatory effect of 8-Br-cAMP. Conversely, the ability of PMA to enhance $\left[{ }^{3} \mathrm{H}\right] \mathrm{ACh}$ release requires concomitant activation of PKA, as it was prevented by the cyclic AMP antagonist, Rp-cAMPS (see fig. 6). These results further suggest that the involvement of PKA yielding to $\mathrm{Ca}^{2+}$ mobilization through $\mathrm{Ca}_{\mathrm{v}} 1$ (L-type) channels may be secondary to PKC activation by $\mathrm{M}_{1}$ receptors. It is worth noting that cross-talk leading to sequential activation of the two-enzymatic cascades has been observed in heterologous expression systems [40, 41]. Reversible PKA phosphorylation of $\mathrm{Ca}_{\mathrm{v}} 1$ (L-type) channels may underlie activity-dependent enhancement of neurotransmitter release [42]. While constitutive PKA phosphorylation of $\mathrm{Ca}_{\mathrm{v}} 1$ (L-type) channels may give an alternative explanation for the observation that Rp-cAMPS inhibits PKC-induced $\mathrm{M}_{1}$ enhancement of $\left[{ }^{3} \mathrm{H}\right] \mathrm{ACh}$ release, this 
would hardly account for the functional weakening of McN-A-343 facilitation in the presence of activators of the adenylate cyclase/cyclic AMP system, FSK, ROL, and 8-Br-cAMP [cf. 13].

In conclusion, our observations provide evidence that the negative interplay between muscarinic $\mathrm{M}_{1}$ and adenosine $\mathrm{A}_{2 \mathrm{~A}}$ receptors operating facilitation of $\left[{ }^{3} \mathrm{H}\right] \mathrm{ACh}$ release from the rat motor nerve terminals might be due to signal convergence to a common pathway involving PKA activation and $\mathrm{Ca}^{2+}$ recruitment through 'quiescent' $\mathrm{Ca}_{\mathrm{v}} 1$ (L-type) channels (fig. 6). This mechanism may be crucial to prevent neurotransmitter overflow during intense neuronal firing, a situation where the adenosine $\mathrm{A}_{2 \mathrm{~A}}$-mediated tonus becomes predominant $[2,15]$. It also provides a molecular basis to elucidate some of the inconsistencies found in the literature about the muscarinic regulation of evoked ACh from stimulated motor nerve terminals.

\section{Acknowledgements}

This work was supported by Fundação para a Ciência e a Tecnologia (FCT) grants POCTI/FCB/36545/2000 and POCTI/ CVT/43368/2001. L. Oliveira was in receipt of an FCT PhD studentship. We thank Dr. M.A. Timóteo and Dr. A. Barroso for their valuable collaboration in some experiments. We also thank Mrs. M. Helena Costa e Silva, Suzete Liça and Belmira Silva for their technical assistance.

\section{References}

1 Sebastião AM, Ribeiro JA: Fine-tuning neuromodulation by adenosine. Trends Pharmacol Sci 2000;21:341-346.

\2 Oliveira L, Timóteo MA, Correia-de-Sá P: Modulation by adenosine of both muscarinic $\mathrm{M}_{1}$-facilitaton and $\mathrm{M}_{2}$-inhibition of $\left[{ }^{3} \mathrm{H}\right]$-acetylcholine release from the rat motor nerve terminals. Eur J Neurosci 2002;15:1728-1736.

3 Re L: Modulation of acetylcholine release by presynaptic muscarinic autoreceptors. Acta Physiol Pharmacol Ther Latinoam 1999;49: 215-223.

-4 Caulfield MP, Birdsall NJM: International Union of Pharmacology. XVII Classification of muscarinic acetylcholine receptors. Pharmacol Rev 1998;50:279-290.

5 Correia-de-Sá P, Ribeiro JA: Evidence that the presynaptic $\mathrm{A}_{2 \mathrm{~A}}$-adenosine receptor of the rat motor nerve endings is positively coupled to adenylate cyclase. Naunyn Schmiedebergs Arch Pharmacol 1994;350:514-522.

6 Tsien RW, Lipscombe D, Madison DV, Bley KR, Fox AP: Multiple types of neuronal calcium channels and their selective modulation. Trends Neurosci 1988;11:431-438.

7 Robitaille R, Adler EM, Charlton MP: Strategic location of calcium channels at transmitter release sites of frog neuromuscular junctions. Neuron 1990;5:773-779.

-8 Correia-de-Sá P, Timóteo MA, Ribeiro JA: Influence of stimulation on $\mathrm{Ca}^{2+}$ recruitment triggering $\left[{ }^{3} \mathrm{H}\right]$ acetylcholine release from the rat motor-nerve endings. Eur J Pharmacol 2000;406:355-362.

-9 Somogyi GT, Zernova G, Tanowitz M, de Groat WC: Role of L- and N-type $\mathrm{Ca}^{2+}$ channels in muscarinic receptor-mediated facilitation of $\mathrm{ACh}$ and noradrenaline release in the rat urinary bladder. J Physiol (Lond) 1997;499: 645-654.
10 Correia-de-Sá P, Timóteo MA, Ribeiro JA: A 2 A adenosine receptor facilitation of neuromuscular transmission: influence of stimulus paradigm on calcium mobilization. J Neurochem 2000; 74:2462-2469.

11 Carbone E, Carabelli V, Cesetti T, Baldelli P, Hernández-Guijo JM, Giusta L: G-Proteinand cAMP-dependent L-channel gating modulation: a manifold system to control calcium entry in neurosecretory cells. Pflügers Arch 2001;442:801-813.

-12 Arenson MS, Evans SC: Activation of protein kinase $\mathrm{C}$ increases acetylcholine release from frog motor nerves by a direct action on L-type $\mathrm{Ca}^{2+}$ channels and apparently not by depolarisation of the terminal. Neuroscience 2001;104: 1157-1164.

13 Sculptoreanu A, Yoshimura N, de Groat WC, Somogyi GT: Protein kinase $\mathrm{C}$ is involved in $\mathrm{M}_{1}$-muscarinic receptor-mediated facilitation of L-type $\mathrm{Ca}^{2+}$ channels in neurons of the major pelvic ganglion of the adult male rat. Neurochem Res 2001;26:933-942.

14 Cordeaux Y, Hill SJ: Mechanisms of cross-talk between G-protein-coupled receptors. Neurosignals 2002; 11:45-57.

15 Correia-de-Sá P, Timóteo MA, Ribeiro JA: Presynaptic $A_{1}$ inhibitory/A $A_{2 A}$ facilitatory adenosine receptor activation balance depends on motor nerve stimulation paradigm at the rat hemidiaphragm. J Neurophysiol 1996; 76:3910-3919.

16 Wessler I, Kilbinger H: Release of $\left[{ }^{3} \mathrm{H}\right]$-acetylcholine from a modified rat phrenic nervehemidiaphragm preparation. Naunyn Schmiedebergs Arch Pharmacol 1986;334:357-364.

17 Laurenza A, Sutkowski EMcH, Seamon KB: Forskolin: a specific stimulator of adenylate cyclase or a diterpene with multiple sites of action. Trends Pharmacol Sci 1989; 10:442447.

18 Dunlap K, Luebke JI, Turner TJ: Exocytotic $\mathrm{Ca}^{2+}$ channels in mammalian central nervous system. Trends Neurosci 1995;18:89-98.
19 Bowman WC, Marschall IG, Gibb AJ, Harborne AJ: Feedback control of transmitter release at the neuromuscular junction. Trends Pharmacol Sci 1988;9:16-20.

20 Faria M, Oliveira L, Timóteo MA, Lobo MG, Correia-de-Sá P: Blockade of neuronal facilitatory nicotinic receptors containing $\alpha 3 \beta 2$ subunits contribute to tetanic fade in the rat isolated diaphragm. Synapse 2003;49:77-88.

21 Wessler I, Halank M, Rasbach J, Kilbinger H: Presynaptic nicotine receptors mediating a positive feed-back on transmitter release from the rat phrenic nerve. Naunyn Schmiedebergs Arch Pharmacol 1986;334:365-372.

22 Colquhoun D, Mathie A, Mulrine NK, Ogden DC: Studies on single acetylcholine-receptor channels in muscle endplate and sympathetic neurons; in Sellin LC, Libelius R, Thesleff S (eds): Neuromuscular Junction. Amsterdam, Elsevier, 1989, pp 217-234.

23 Wessler I: Control of transmitter release from the motor nerve by presynaptic nicotinic and muscarinic autoreceptors. Trends Pharmacol Sci 1989;10:110-114.

24 Santafé MM, Salon I, Garcia N, Lanuza MA, Uchitel $\mathrm{OD}$, Tomàs J: Modulation of $\mathrm{ACh}$ release by presynaptic muscarinic autoreceptors in the neuromuscular junction of the newborn and adult rat. Eur J Neurosci 2003;17:119127.

25 Dixon AK, Widdowson L, Richardson PJ: Desensitisation of the adenosine $A_{1}$ receptor by the $\mathrm{A}_{2 \mathrm{~A}}$ receptor in the rat striatum. J Neurochem 1997;69:315-321.

-26 Lopes LV, Cunha RA, Ribeiro JA: Cross-talk between $A_{1}$ and $A_{2 A}$ adenosine receptors in the hippocampus and cortex of young adult and old rats. J Neurophysiol 1999;82:3196-3203.

27 Schulte G, Fredholm BB: Diverse inhibitors of intracellular signalling act as adenosine receptor antagonists. Cell Signal 2002;14:109-113. 
28 Liu M, Simon MI: Regulation by cAMP-dependent protein kinase of a G-protein-mediated phospholipase C. Nature 1996;382:8387.

29 Rhee SG, Bae YS: Regulation of phosphoinositide-specific phospholipase C isozymes. J Biol Chem 1997;272:15045-15048.

-30 Wojcikiewicz RJ, Luo SG: Phosphorylation of inositol 1,4,5-trisphosphate receptors by cAMP-dependent protein kinase. Type I, II and III receptors are differentially susceptible to phosphorylation and are phosphorylated in intact cells. J Biol Chem 1998;273:56705677.

-31 Houslay MD: 'Cross-talk': a pivotal role for protein kinase $\mathrm{C}$ in modulating relationships between signal transduction pathways. Eur $\mathrm{J}$ Biochem 1991;195:9-27.

- 32 Lai HL, Yang TH, Messing RO, Ching YH, Lin SC, Chern Y: Protein kinase C inhibits adenylate cyclase type VI activity during desensitization of the $\mathrm{A}_{2 \mathrm{~A}}$-adenosine receptor-mediated cAMP response. J Biol Chem 1997;272: 4970-4977.
33 Parfitt KD, Madison DV: Phorbol esters enhance synaptic transmission by a presynaptic, calcium-dependent mechanism in rat hippocampus. J Physiol (Lond) 1993;471:245-268.

34 Chavez-Noriega LE, Stevens CF: Increased transmitter release at excitatory synapses produced by direct activation of adenylate cyclase in rat hippocampal slices. J Neurosci 1994;14: 310-317.

35 Turner KM, Burgoyne RD, Morgan A: Protein phosphorylation and the regulation of synaptic membrane traffic. Trends Neurosci 1999;22: 459-464.

36 Shapiro MS, Loose MD, Hamilton SE, Nathanson NM, Gomeza J, Wess J, Hille B: Assignment of muscarinic receptor subtypes mediating G-protein modulation of $\mathrm{Ca}^{2+}$ channels by using knockout mice. Proc Natl Acad Sci USA 1999;96:10899-10904.
37 Brown JH, Rietow M: Muscarinic-dopaminergic synergism on retinal cyclic AMP formation. Brain Res 1981;215:388-392.

38 Enyedi P, Fredholm BB, Lundberg JM, Änggard A: Carbachol potentiates the cyclic AMPstimulating effects of VIP in cat submandibular gland. Eur J Pharmacol 1982;79:139-143.

39 Oliana MC, Onali P: Properties of muscarinic stimulated adenylate cyclase activity in rat olfactory bulb. J Neurochem 1992;58:17231729.

40 Felder CC, Kanterman RY, Ma AL, Axelrod J: A transfected $\mathrm{m} 1$ muscarinic acetylcholine receptors stimulates adenylate cyclase via phosphatidylinositol hydrolysis. J Biol Chem 1989; 264:20356-20362.

41 Jones SV, Heilman CJ, Brann MR: Functional responses of cloned muscarinic receptors expressed in CHO-K1 cells. Mol Pharmacol 1991;40:242-247.

42 Sculptoreanu A, Figourov A, de Groat WC: Voltage-dependent potentiation of neuronal Ltype calcium channels due to state-dependent phosphorylation. Am J Physiol 1995;269: C725-C732. 